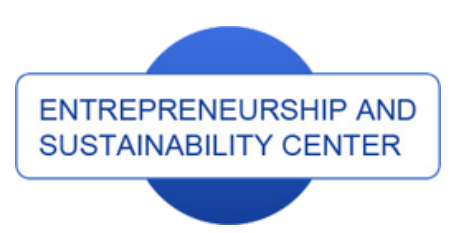

Publisher

http://jssidoi.org/esc/home enterprise

europe

network

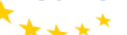

Business Support on Your Doorstep

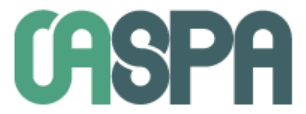

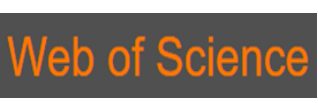

1) Clarivate

Analytics

\title{
IMPACT OF LABOUR MIGRATION ON ENTREPRENEURSHIP ECOSYSTEM: CASE OF EURASIAN ECONOMIC UNION
}

\author{
Georgi N. Todorov', Anna V. Kalinina², Anna I. Rybakova ${ }^{3}$ \\ ${ }^{1}$ Varna Scientific Institute of the Eastern European Commonwealth - VSIEEC, \\ Slivnitsa Blvd, 9009, Varna, Bulgaria \\ ${ }^{2}$ Tyumen Industrial University, \\ 38 Volodarskogo Str., Tyumen, 625000, Russian Federation \\ ${ }^{3}$ Russian State Social University, \\ 4/1 Wilhelm Pieck Str., Moscow, 129226, Russian Federation \\ E-mails: ${ }^{1}$ todorov.g@protonmail.com; ${ }^{2}$ kalinina@ymservices.ru; ${ }^{3}$ anya-rybakova@list.ru
}

Received 18 February 2018; accepted 10 May 2018; published 30 June 2018

\begin{abstract}
Labour migration is one of the most important socio-economic development indicators. The problem of a steady decline in the working-age population size has changed a role of migration that has an active impact on the human potential development. With the help of an empirical example from the Eurasian Economic Union (EEU), this research paper presents specifics of labour migration. A review of literary sources points out to an ambiguous impact of a number of factors on dynamics of migration flows, employment, and unemployment. Correlation-regression modelling of migration processes for the EEU in various configurations has resulted with the following. First, a revealed direct relationship between a natural growth (decline) in the population, a number of vacant jobs and the population migration indicator. Second, researchers have established an inverse dependence between GDP per capita, consumer price index, minimum wage, unemployment rate, and population migration indicator. Thirdly, they have shown that a direction of migrant flows depends on such factors, as GDP per capita, number of vacant jobs and minimum wage. Results of the analysis show that an increasing difference between an average wage in the region and across the EEU, and minimum standard of living leads to decreasing numbers of migrants from a particular region of the EEU. In the EEU, for the population main reasons for employment abroad include unemployment in rural areas, no regular income, and lower wages compared to neighbouring countries. The discussion explains an essence of contradictory consequences of the labour migration impact on a development of national economic systems in terms of the completed academic and empirical research. In this regard, it is reasonable to consider labour migration as a global economic phenomenon and this needs further research in terms of factors that influence it.
\end{abstract}

Keywords: labour migration; Eurasian Economic Union (EEU), employment; labour remuneration; migration flows; entrepreneurship ecosystem; migration factors

Reference to this paper should be made as follows: Todorov, G.N.; Kalinina, A.V.; Rybakova, A.I. 2018. Impact of labour migration on entrepreneurship ecosystem: case of Eurasian Economic Union, Entrepreneurship and Sustainability Issues 5(4): 992-1007.

http://doi.org/10.9770/jesi.2018.5.4(20) 


\section{Introduction}

So far, the process of globalization has had an objective and, at the same time, contradictory nature. It relies upon modified functions of international trade, economy development with a network structure and developed outsourcing relationships, an emergence of the global labour market with internationalized workers (Department of Economic and Social Affairs, 2004, p. 138; Singer, 2000; Pekarskiene, Laskiene, Saboniene \&Susniene, 2017; Potrafke, 2010, pp. 545-571). In such conditions, migration processes have continued to become more active with a development of global integration that contributes to this.

A wide range of all forms of international economic relations, foreign trade, production and its cooperation in particular, invariably results in a flow of capital accompanied with a movement of the main production factor, i.e. the labour force (Savin \& Savina, 2016, pp. 78-83). The population migration is a process that overreacts to socioeconomic transformations (Baccaïni, 2007, 139-155; Commission on Population and Development, 2013), and largely projects such trends, as regional differentiation and inequality (Rayp, 2013).

With considerations of the Eurasian Economic Union as a promising macro region (the EEU includes Armenia, Belarus, Kazakhstan, Kyrgyzstan, and Russia) it is possible to conclude with confidence that employment opportunities between associated countries are still limited. In the formal sector of the EEU, employment often does not meet requirements for labour force reproduction. Under such the circumstances, labour migration remains a priority to ensure an acceptable standard of living for a large part of the employable population. Migration plays an important role in the development of the common labour market in the EEU. In the review of socio-economic conditions and consequences of the migration movement, we should take into account differences living standards and life quality of the population as in the EEU regional differentiation is very high. Therein, active processes of external migration in the EEU show a clear need for a detailed research of this phenomenon.

Each region in the EEU has its territorial and socio-economic specifics, which causes different levels of labour migration of the population, both national and intercountry. The valid migration policy in the EEU often focuses on narrow economic considerations of labour migration as a source of a labour force, or, in demographic terms, as a substitute for a natural decline in the population (Usmanova \& Azimova, 2017). This objectively leads to a need in a control over external labour migration.

Globalization has also affected a role of the human factor in the social and economic development, which is a direct capital. Labour migration makes a significant part of this capital (Delogu, Docquier, \& Machado, 2018, 136). This function of migration centers on its quantitative parameters. As its property, international migration of the population has a steady growth in its size. Its structural characteristics are getting of great importance for understanding a role of labour migration in social processes.

In migration processes, changes in time occur under an influence of factors different in nature. In a statistical study of the population labour migration, there is a dynamical analysis among other directions. The dynamics study in a movement of labour migrants will contribute in identification of regularities and intensity specifics when it appears. Migration causes are heterogeneous, their joint impact on the process leads to levelling or a significant increase in migration flows. Sometimes, revealed influence patterns are in contradiction to each other. 
The International Journal

ENTREPRENEURSHIP AND SUSTAINABILITY ISSUES

ISSN 2345-0282 (online) http://jssidoi.org/jesi/

2018 Volume 5 Number 4 (June)

http://doi.org/10.9770/jesi.2018.5.4(20)

It is customary to identify the following main causes of labour mobility of the population, including imbalance in the country development, income differentiation (Usmanova \& Azimova, 2017, 177-182), demographic factors caused by imbalances in a natural movement of the population, cost of labour, high unemployment rate, inflation, economic crisis, etc. (Namatov, 2016, pp. 67-70). At the same time, some researchers (Dosaliev, 2016, pp. 127130) have found that the level of competitiveness and wage level are inversely proportional. The high value of the latter makes competitiveness lower partly due to labour migration. Among other reasons, there is a location of equity, which acts as a stimulating motive for labour migration (Chernenko, 2015, pp. 50-56).

This leads to the fact that multifacetedness in today's migration processes necessitates a demand and need in new approaches that will allow evaluating an influence, contradictory consequences and revealing a development potential inherent in international labour migration. In this regard, tasks of identification of factors that encourage the population to migrate or limit it, tasks of quantitative measurement of migration flows, acquire certain significance. That is why we will attempt to establish regularities in the influence of a number of factors on labour migration using the correlation-regression analysis of migrants' movement according to the model with various specifications.

\section{Literature review}

Internationalization is one of today's economic trends of recent times. In this regard, a role of foreign economic activity and, especially, in cases when it is associated with labour migration, significantly increases. From a theoretical point of view, we can see labour migration as a mechanism for redistribution of labour forces in the international labour market. Let us analyse some concepts that will contribute to understanding and explain the motives encouraging labour migration.

There are a number of academic theories that explain directions and causes of international migration processes. The conceptual approach is the most common. It includes the classical economic theory and, in particular, relies upon a ratio of stimulating factors that either 'attract' or 'push out'. According to the theory of historical structuralism by Castles (Lindert, 1992; Sassen, 1988; Portes \& Rumbaut, 1990), migration is a way to mobilize cheap labour forces for developed countries and the government and corporations form migration flows. Early concepts explain a process of migration by political, economic factors and inequality of various actors, including countries, regions, enterprises and individuals (Trofimova, 2010, pp. 75-85). These theories recognize importance and necessity of national factors, as well as a role of government regulation in this sector.

According to classical and neoclassical economic theories, excess labour resources move to more urbanized areas with high labour efficiency (Efimov, \& Katsan, 2010, pp. 19-27). Of the theories that attempt to explain international migration of the population at the macro level, it is also necessary to refer to the theory of pancapitalism, which explains development of three main types of relocation: 'manual' migration of people, migration because of intellectual and political reasons.

An attempt to find a complex relationship between a migration country and host country relied upon the concept of dual/fragmentized character of the labour market (Doeringer \& Piore, 1971, pp. 13-28). Its core is an assumption that growing interdependence of countries plays a decisive role with subsequent equalization of supply and demand for the labour force within the framework of macro-associations. Because of market harmonization, new factors arise that give rise to certain growth points for the economic development of countries. 
The International Journal

ENTREPRENEURSHIP AND SUSTAINABILITY ISSUES

ISSN 2345-0282 (online) http://jssidoi.org/jesi/

2018 Volume 5 Number 4 (June)

http://doi.org/10.9770/jesi.2018.5.4(20)

Within the framework of academic approaches, there are different levels of analysis regarding an origin and development of labour migration. Quite often concepts do not comply with each other. Besides, these academic approaches cannot sometimes explain individual manifestations of migration.

A number of today's approaches to reasoning of international labour migration processes create new opportunities for understanding mechanisms that govern migration processes. In particular, there are Massey (Massey, 2007, pp. 146-172) with his synthetic theory, Glick with his theory of transnational migration (Glick, Bash, \& BlancSzanton, 1992), Kritz with his theory of migration systems (Kritz, Lim, \& Zlotnik, 1992), and Rozenau's theory of interdependence (Rosenau, 1993, p. 499).

Taking into account growing scales of labour migrations in the modern world, there is an urgent need to combine the mentioned concepts within a single fundamental paradigm that would provide an opportunity to have comprehensive answers regarding causes of creation, operational specifics, and socioeconomic consequences of labour migration, in the context of the EEU integration into the world's labour market in particular.

Note that the world's labour market depends on institutional flexibility in national markets, which determines mobility of the workforce. Institutional flexibility of the labour market is subject, first, by norms of legislation, but other institutional factors play a particular role, which include: an approach to formation of wages and compensation package, indexation procedure, insurance system, role of trade union organizations, interaction with the market of educational services, etc. (Department of Economic and Social Affairs, 138). All this factors influence a rate in inter-sector redistribution of labour forces, a pace of a change in the employment structure, and a use of non-standard forms of work, mobility, working hours, wage changes depending on business activism and economic cycles (Tsvylev, Rydvanov, \& Zhiritsky, 1994, p. 30) (Tsvylev, Rydvanov, \& Zhiritsky, 1994, p. 30). These and other features constitute a factor model of labour migration.

Sources give a diverse typology of interrelated factors that influence directions and scales of labour migration processes. An analysis of migration causes and factors relies upon the classification by Massey and Skurl (Massey et al., 1998). As we have mentioned above, the factors that influence a movement of the employable population act simultaneously, and are to some extent interdependent, and sometimes opposed to each other. Therefore, it is very difficult to find sources of separate migratory processes.

Labour migration has both positive and negative sides. Thus, it has been confirmed that an overall benefit from liberalization of a migration regime would be about several times higher than an effect from trade liberalization (Rodrik, 2002; Overcoming Barriers: Human Mobility and Development, 2009). Migration has virtually no negative impact on unemployment and wage level in host countries (Haisken-DeNew \& Zimmerman, 1995; Brücker, 2002; König \& Koskela, 2011, pp. 21-38). According to empirical data from the USA and several EEU countries, a conclusion is possible that an impact of migration on employment and unemployment is not so significant (Glushchenko, 2008, pp. 65-79). The connections that arise from labour migration, most often even increase employment levels. For instance, Brucker (2002) found the following: wages of blue-collar workers will only drop by $1.05 \%$, while that of white-collar workers will increase by $0.18 \%$ if a share of migrants in the labour force grows by $1 \%$ (if the labour market is in equilibrium). If the labour market is not in equilibrium, wages of blue-collar workers will fallen by $0.58 \%$ (unemployment will get $0.85 \%$ higher), while wages of highly skilled workers will get $0.19 \%$ lower (unemployment will increase by 0.05\%) (Samrailova \& Veshkurova, 2010, p. 1321).

According to other sources, labour migration makes an average level of labour remuneration in a region (sector) lower and, accordingly, cuts down tax revenues to the budget (Khrustalev \& Slavyanov, 2014, pp. 79-86). We can explain this with the fact that foreign workers get incomes and do not accumulate them as savings. Instead, they 
transfer them abroad in foreign currency (Gotovtseva, Ryazantsev, \& Khrustalev, 2012). Micco and Pages share the same position. They refer to a significant impact on social division and a size of labour remuneration, as well as a level of social tension in regions with a long and intensive inflow and, on the contrary, outflow of the locals (Micco \& Pages, 2006, p. 6). There is also a simultaneous impact on overall and structural insufficiency of region's labour resources; international labour migration mitigates such aspects. Employment of immigrants results in higher elasticity in the labour market. At the same time, researchers have found that there is a steady correlation between levels of education, professional qualifications and population mobility (Suliagina, 2016, pp. 185-189).

Historical experience confirms a close relationship between migration and development in the employment sector. However, at the present stage, a nature of this relationship is much more diverse. Migration processes also entail changes in social and demographic structures of the society. It is noteworthy that migrant workers contribute to establishment and support of communication between countries (Nazarov, 2012, pp. 82-86). Thus, migration is a significant stimulus for the world economy development, redistributing the population between countries.

In this connection, the problem of international labour migration and its impact on national labour markets in terms of globalization seems to be currently central, as well as a need in labour mobility research. The study of labour migration in time will allow assessing an impact of factors on employment and identifying main development trends.

\section{Materials and Methods}

We believe that we should make an empirical analysis of migration in the EEU with a focus on the most significant factors of migration. The observation period includes 2006-2017 with an interval of 1 quarter except for a number of indicators, for which statistical data are limited (Annex). The main sources of data were the information resources of Rosstat, IMF, central banks in the EEU countries, and the EEU Statistics Department.

Note that since 2014, in many sectors of economy, there has been an observed decline, while labour migration has had a steady growth. It is what has helped to mitigate serious consequences of an economic slowdown, making a fractal compensation for lost income from exported raw materials and goods at the expense of remittances made by migrants. Statistics of the Russia's Central Bank (Russia's Central Bank) and international payment systems evidence it as a result for 2016-2017, according to which a volume of remittances from Russia to Uzbekistan and Tajikistan decreased, and to Kyrgyzstan and Kazakhstan, on the contrary, increased. Mentioned trends highlight serious changes that have recently taken place in labour migration in the EEU. This is because the Russian Federation remains a main centre for migrants' attraction.

Before a regression analysis, experts had built a correlation matrix to identify a relationship between endogenous and exogenous variables, investigated co-linearity and covariance of factors. Having reviewed sources for a primary analysis, experts selected several factors (variables) that influence migration, including GDP per capita, remittances between countries in the Union, exported goods and services, employment rate of the employable population, unemployment, purchasing power of a national currency, consumer price index, cost of borrowings, increase in the population, average and minimum wages in a country, a number of economically active people. Not all the variables have confirmed their validity, a number of factors have been excluded. This highlights that some approaches discussed in the literature review are incompatible and inconsistent. We tested whether it was possible to use the parameter of the demand in the workforce based on resource balance, where excessive or deficient numbers of workers in a national market reasonably lead to formation of migration conditions.

The econometric model relies on hypotheses of dependencies in a migration flow. 
First, empirical data indicate that there is a direct dependence between a natural growth (decline) in the population, specific weight of borrowing cost, number of vacant jobs and population migration index in the EEU;

Second, such indicators as GDP per capita, consumer price index, minimum wage and unemployment rate in a country of the Union are inversely related to migrations of the population in the EEU.

A number of migrants from the country (Emigr) is a dependent variable in the model. We estimated statistical significance of coefficients using Student's t statistics and compared with the t-test. Individual indicators were statistically insignificant (therefore excluded from a sample). Note that we logarithmized variable numbers of migrants from the country and GDP per capita in order to improve normal distribution of residuals and minimize standard errors of the model with the data measured in various units.

In its generalized form, the initial model looks like the following (1):

$$
\begin{aligned}
& \text { Emirg }_{i}=\alpha+\beta_{1} \text { GDP } \text { p }_{t}+\beta_{2} \text { Unemp }_{1}+\beta_{3} \text { Price }_{t}+ \\
& +\beta_{4} \text { Cred_eac }+\beta_{5} \text { Cred }+\beta_{6} \text { Wage }_{t}+\beta_{6} \text { Jobvac }_{t}+\beta_{7} \text { Pop } \_n e t_{t}+\varepsilon_{t}
\end{aligned}
$$

where Emigr is a number of migrants from a country; GDP_p is GDP per capita; Unemp is an unemployment rate; Price is a consumer price index; Cred_eac is a cost of loans in national currency; Cred is a cost of loans in foreign currency; Wage is a minimum wage; Jobvac is a need of enterprises in workers; Pop_net is a balance of natural increase (decrease) of the population; $\alpha$ is a free variable that reflects an influence of missed factors not included in the observation; $\beta_{1}, \ldots, \beta_{7}$ are unknown coefficients of the model; $\mathrm{t}$ is a time variable; $\varepsilon_{\mathrm{t}}$ is a standard error.

Note separately that due to high values of correlation coefficients between individual independent variables and a disproportionately large number of variables relative to a number of observations per object unit, the presented model was analysed in 3 specifications, i.e. (1)-(3):

$$
\begin{aligned}
& \text { InEmigr }_{t}=\alpha+\beta_{1} \ln G D P_{-} p_{t}+\beta_{2} \text { Unemp }_{t}+\beta_{7} \text { Pop }_{-} \text {net }_{t}+\varepsilon_{t}, \\
& \text { InEmigr }_{t}=\alpha+\beta_{3} \text { Price }_{t}+\beta_{5} \text { Cred }_{+} \beta_{6} \text { Jobvac }_{t}+\varepsilon_{t} \text {, } \\
& \text { InEmigr } r_{t}=\alpha+\beta_{3} \text { Price }_{t}+\beta_{6} \text { Wage }_{t}+\varepsilon_{t} \text {. }
\end{aligned}
$$

In studies of such a complex and heterogeneous phenomenon as labour migration, it is necessary to apply the statistical approach in order to compare migration indicators. In this sense, a comprehensive analysis of structural changes is an important direction in studies of available disparities in labour migration. It is necessary to identify changes in the socio-demographic structure of the population, in particular, in its employable part in an active development of migration flows. The statistical approach makes it possible to evaluate characteristic directions in a movement of labour resources influenced by various factors. It is important to find out a degree of mobility for the structure, its stability, and strength. A further comparative analysis makes it possible to explore positive and negative trends in structural shifts of labour migration in the EEU. 


\section{Results and discussion}

\subsection{Structural analysis of migration flows in the EEU}

We will analyse dynamics of numbers of labour migrants in the EEU by main socio-demographic characteristics in 2006-2017, which we consider in the context of certain characteristics (Table 1). Let us consider the distribution of numbers of labour migrants in the EEU by age and sex groups. The analysis of dynamics showed that there was a decrease in a share of labour migrants among people aged 40-49, almost among all categories of the population. Along with this, an increase in the overall gain for numbers of labour migrants was observed among people in their pre-retirement age (50-59 years) and middle-age groups (aged 25-29, aged 30-34).

Table 1. Social and demographic structure of labour migrants in the EEU

\begin{tabular}{|c|c|c|c|c|}
\hline \multirow[b]{2}{*}{ Age groups } & \multicolumn{2}{|c|}{ Labour migrants, $\%$} & \multirow[b]{2}{*}{ Overall gain } & \multirow[b]{2}{*}{ Gain rate, $\%$} \\
\hline & 2013 & 2017 & & \\
\hline \multicolumn{5}{|c|}{ Women: } \\
\hline Aged 15-24 & 12.0 & 12.0 & 0.0 & 0.0 \\
\hline Aged 25-29 & 12.3 & 8.7 & $-3,6$ & -29.2 \\
\hline Aged 30-34 & 16.6 & 17.4 & 0.8 & 4.8 \\
\hline Aged 35-39 & 14.2 & 13.1 & -1.1 & -7.7 \\
\hline Aged 40-49 & 30.2 & 24.2 & -6.0 & -19.9 \\
\hline Aged 50-59 & 14.7 & 20.9 & 6.2 & 42.1 \\
\hline Aged 60-70 & - & 3.7 & & \\
\hline Total & 100 & 100 & & \\
\hline \multicolumn{5}{|c|}{ Men: } \\
\hline Aged 15-24 & 16.8 & 10.3 & -6.5 & -38.7 \\
\hline Aged 25-29 & 15.1 & 19.5 & 4.4 & 29.1 \\
\hline Aged 30-34 & 15.2 & 18.8 & 3.6 & 23.7 \\
\hline Aged 35-39 & 14.9 & 13.6 & -1.3 & -8.7 \\
\hline Aged 40-49 & 28.9 & 25.9 & -3.0 & -10.4 \\
\hline Aged 50-59 & 9.1 & 11.6 & 2.5 & 27.5 \\
\hline Aged 60-70 & - & 0.3 & & \\
\hline Total & 100 & 100 & & \\
\hline \multicolumn{5}{|c|}{ Urban population } \\
\hline Aged 15-24 & 13.9 & 9.2 & $-4,7$ & -33.8 \\
\hline Aged 25-29 & 13.0 & 15.5 & 2.5 & 19.2 \\
\hline Aged 30-34 & 16.2 & 20.3 & 4.1 & 25.3 \\
\hline Aged 35-39 & 15.3 & 13.7 & -1.6 & -10.5 \\
\hline Aged 40-49 & 29.8 & 23.3 & -6.5 & -21.9 \\
\hline Aged 50-59 & 11.8 & 15.2 & 3.4 & 28.8 \\
\hline Aged 60-70 & - & 2.8 & & \\
\hline Total & 100 & 100 & & \\
\hline \multicolumn{5}{|c|}{ Rural population } \\
\hline Aged 15-24 & 16.8 & 12.6 & $-4,2$ & -23.6 \\
\hline Aged 25-29 & 15.6 & 15.9 & 0.3 & 1.9 \\
\hline Aged 30-34 & 15.1 & 16.6 & 1.5 & 9.9 \\
\hline Aged 35-39 & 13.9 & 13.1 & -0.8 & -5.8 \\
\hline Aged 40-49 & 28.7 & 27.0 & -1.7 & -6.0 \\
\hline Aged 50-59 & 9.9 & 14.5 & 4.6 & 46.5 \\
\hline Aged 60-70 & - & 0.3 & & \\
\hline Total & 100 & 100 & & \\
\hline
\end{tabular}

Source: Integrated data of the Statistics Department of the Eurasian Economic Commission. 
The International Journal

ENTREPRENEURSHIP AND SUSTAINABILITY ISSUES

ISSN 2345-0282 (online) http://jssidoi.org/jesi/

2018 Volume 5 Number 4 (June)

http://doi.org/10.9770/jesi.2018.5.4(20)

There are higher overall gains in numbers of migrant workers in such population groups as: women aged 50-59, by 6.2 ; men aged $25-29$, by 4.4 , urban population aged $30-34$, by 4.1 , and rural population aged $50-59$, by 4.6. Higher overall gain rate is observed respectively among women aged 50-59, 42.1\%, men aged 25-29, 29.1\% increase, urban population, $25.3 \%$ increase, and rural population, 46,5\% increase. Having compared the distribution of labour migrants, we can state that there are some certain shifts: first, there was a smaller share of labour migrants in three age groups: $15-25$, by 4.3 p.p., 35-39, by 1.2 p.p., and 40-49, by 4.0 p.p.; second, in other age groups, there was higher proportion of labour migrants, in particularly among middle-aged people (aged 2526 by 1.6 p.p., aged 30-34 by 2.6 p.p.), and older groups (aged 50-59 by 3.9 p.p., aged 60-70 by 1.4 p.p.).

Findings show that in 2017, compared to 2013, there was an increase in numbers of labour migrants of the male population across almost all age groups. Among women, there is a growth in labour migrations in the groups of those aged 30-34 and 50-59. Among the urban population, there was an increase in labour migrants in middle and elderly age groups. The largest number of labour migrants among the rural population was in the group of people aged 25-29, 30-34, and 50-59. The findings point out to increased numbers of labour migrants among employable men, which in turn lead to a worse situation in national labour markets in 'donor' countries (Armenia, Kazakhstan, and Kyrgyzstan), where there was a decline in numbers of the employed by occupational groups. Enhanced labour flows among the population of young and middle age lead to nation ageing, and this deteriorates the demographic situation in the EEU. Ivanova (2008, pp. 82-97) referred to similar trends in the case of Russia. Table 2 presents the indicators that say of structural shifts related to labour migrants and their main components by age group in the EEU in 2013-2017.

Table 2. Consolidated evaluation of structural shifts among labour migrants in the EEU

\begin{tabular}{|c|c|c|c|c|}
\hline Categories of migrant workers & JwA, pp. & JwQ, pp. & RwQ,\% & RwA, pp. \\
\hline By age group, total & 2.71 & 2.99 & 19.64 & 0.68 \\
\hline women & 3.06 & 3.83 & 22.33 & 0.76 \\
\hline men & 3.09 & 3.62 & 24.00 & 0.77 \\
\hline urban population & 3.66 & 3.95 & 23.82 & 0.91 \\
\hline rural population & 1.91 & 2.53 & 18.76 & 0.48 \\
\hline By education level, total & 3.70 & 4.15 & 19.47 & 0.53 \\
\hline women & 3.40 & 4.18 & 20.01 & 0.49 \\
\hline men & 5.85 & 6.24 & 26.84 & 0.84 \\
\hline urban population & 2.50 & 3.01 & 15.83 & 0.36 \\
\hline rural population & 4.75 & 6.18 & 25.79 & 0.68 \\
\hline By marital status, total & 1.15 & 1.38 & 10.99 & 0.16 \\
\hline women & 3.05 & 3.42 & 19.62 & 0.44 \\
\hline men & 1.65 & 2.30 & 12.54 & 0.24 \\
\hline urban population & 3.00 & 3.69 & 28.61 & 0.43 \\
\hline rural population & 3.00 & 1.73 & 10.52 & 0.18 \\
\hline By geographical focus, total & 0.26 & 3.41 & 33.47 & 0.95 \\
\hline women & 4.22 & 5.47 & 43.59 & 1.51 \\
\hline men & 2.50 & 2.84 & 32.68 & 0.89 \\
\hline urban population & 3.14 & 4.12 & 40.96 & 1.12 \\
\hline rural population & 2.20 & 2.81 & 25.28 & 0.79 \\
\hline By occupational group, total & 4.40 & 6.26 & 32.85 & 0.94 \\
\hline women & 5.43 & 2.45 & 44.16 & 1.16 \\
\hline men & 4.50 & 6.51 & 51.43 & 0.96 \\
\hline urban population & 4.07 & 4.77 & 26.50 & 0.87 \\
\hline rural population & 6.03 & 8.31 & 56.65 & 1.29 \\
\hline
\end{tabular}

Note: JwA is a linear coefficient of absolute structural shifts, p.p.; JwQ is a quadratic coefficient of absolute structural shifts, p.p.; RwA is a linear coefficient of absolute structural shifts for years, p.p.; RwQ is a quadratic coefficient of relative structural shifts, \%. 
The evaluation of structural shifts related to labour migrants indicates that changes, that are more significant, occurred in the urban population. There was a smaller proportion in groups of people aged 15-24 (by 4.7 p.p.), aged 35-39 (by 1.6 p.p.), and 40-49 (by 6.5 p.p.). There were structural shifts related to labour migrations among the rural population recorded in elderly age groups. There was a higher proportion in groups aged 50-59 (by 4.6 p.p.), and 60-70 (by 0.3 p.p.).

The proportion of separate age groups of migrant workers for the period on the average changed by 2.71 percentage points. The quadratic coefficient of absolute structural shifts was 2.99 p.p. The quadratic coefficient magnitude of relative structural shifts was $19.64 \%$. Thus, the average annual change in all age groups of labour migrants was 0.68 p.p. Experts observed almost the same in the structure of female and male employable population by age groups.

The completed analysis showed almost the same structural changes observed in female and male population groups, related to migrants with basic general secondary or primary level of education. There were minor structural changes observed among men with complete higher education. A higher proportion is among the urban population with complete higher education. The rural population with the basic general secondary education had an opposite situation as in the period under consideration this group's proportion became smaller.

Kapur (2004) identified negative and positive consequences of migrated qualified personnel and such consequences are completely consistent with our findings. On the one hand, countries from which people escape lose their initial investments in education, their human capital gets cheaper, they have a worse situation in certain sectors of economy, and institutional reforms in the society slow down (Kuzmin and Barbakov, 2015, pp. 163170). On the other hand, highly qualified migrants invest the capital in economy of both their host countries, and countries of origin, a transfer of technological knowledge also takes place. All this contributes to higher investment attractiveness of countries (Kapur, 2004).

\subsection{Correlation-regression analysis of labour migration in the EEU}

Taking into account conclusions that it is important to take into account the factors that contribute to population migration to the EEU, let us review how a difference in standards of living and minimum wages influence dynamics of migration flows. For this purpose, researchers built the model that looks like the following (5):

$$
\text { Emirg }_{i}=\alpha+\beta_{1} \text { GDPdif }_{t}+\beta_{2} \text { Wdif }_{t}+\varepsilon_{t}
$$

where Emigr is a number of migrants, persons; GDPdif is a difference between GDP per capita in countries of the EU-20 and EEU, euro; Wdif is a difference between the minimum wage in the EU-20 and EEU; $\alpha$ is a free variable that say of an influence of factors not included in the study; $\beta_{1}, \beta_{2}$ are unknown coefficients of the model; $t$ is a time variable and $\varepsilon_{\mathrm{t}}$ is a standard error.

Note that in the model presented, we estimated variables as absolute measurement as the data presented were comparable without a need of logarithmization. There are results of the model's empirical verification in Table 3. For model $R^{2}$ is $0.753, F_{\text {ct. }}(2.41)=62.752(p$-value $=0.000)$, the Durbin-Watson $(\mathrm{DW})$ criterion is 1.032. 
Table 3. Model coefficients and their statistical evaluation

\begin{tabular}{|l|r|r|r|r|}
\hline \multicolumn{1}{|c|}{ Variable } & Coefficient & Standard. coefficient & $\begin{array}{r}\text { t-stat } \\
(\mathrm{p} \text {-value })\end{array}$ & VIF \\
\hline GDPdif & -0.824 & -0.328 & $\begin{array}{r}-2.109 \\
(0.041) *\end{array}$ & 4.032 \\
\hline Wdif & -46.831 & -0.568 & $\begin{array}{r}-3,651 \\
(0.001) * *\end{array}$ & 4.032 \\
\hline Constant & $54,673.8$ & & $\begin{array}{r}11.50 \\
(0.000) * *\end{array}$ & \\
\hline
\end{tabular}

Note: $* *$ is a statistical significance if the level is $0.01 ; *$ is a statistical significance if the level is 0.05 .

Thus, having modelled an influence of 'attracting' migration factors, we identified that a decreasing difference between minimum wages has the greatest influence on activation of flows of migrants. That is, numbers of migrants increase with a decreasing difference between minimum incomes and this leads to higher wages in the EEU.

Let us consider specifications of the correlation-regression model described earlier, and their statistical evaluations (Table 4). According to the test score in the F-stat, specifications are valid. $\mathrm{R}^{2}$ determination coefficient for all the models is $0.54-0.68$, which is rather high for statistical significance in the correlationregression analysis of data.

Table 4. Statistical evaluation of model's specifications

\begin{tabular}{|c|c|c|c|}
\hline \multirow{2}{*}{ Index } & \multicolumn{3}{|c|}{ Model's specification } \\
\hline & The first & The second & The third \\
\hline $\mathrm{R}^{2}$ & 0.683 & 0.539 & 0.685 \\
\hline $\mathrm{F}_{\text {ctat. }}(\mathrm{p}$-value $=0.000)$ & $28.74(3.40)$ & $10.927(3,28)$ & $44.657(2.41)$ \\
\hline Durbin-Watson criterion (DW) & 1.209 & 1.010 & 0.999 \\
\hline
\end{tabular}

Despite the fact that specifications of the presented model bring meaningful results, note that the model only contains those migration factors that 'push out' and the model does not provide information on those factors that 'attract.' Estimates based on all the specifications for the regression model confirmed general conclusions of available connections between numbers of migrants and GRP per capita. At the same time, we explain 74\% variability of migrant numbers with changed GRP per capita based on the obtained results. According to the calculated coefficient of elasticity, it is possible to conclude that a 10 per cent decrease in GRP per capita results in a $9 \%$ growth in numbers of migrants.

A follow-up for this research might include identification of the most significant social factors at a regional level that affect numbers of migrants. Let us build the following model for a linear regression (6):

$$
\text { Emigr }_{i t}=\alpha+\beta_{1} A v_{-} \text {wagedif }_{i t}+\beta_{2} \text { Wage }_{-} \text {debt }_{i t}+\beta_{3} \text { Wage }_{-} \cos _{i t}+v_{i t}
$$

where Emigr is a number of migrants, Av_wagedif is a difference between average wage in the region and EEU, Wage_debt is wage arrears in the region, Wage_cos is a difference between wage in the region and minimum living wage. 
Let us analyse findings of pooled regression evaluated with the OLS technique. There are statistical estimates of the model in the following table (Table 5), $\mathrm{R}^{2}=0.648368$ :

Table 5. Results of model evaluated with OLS technique by formula (7)

\begin{tabular}{|c|c|c|c|c|c|c|c|}
\hline \multirow{2}{*}{ Variable } & \multirow{2}{*}{ Coefficient $\beta$} & \multirow{2}{*}{$\begin{array}{c}\text { Standard } \\
\text { error }\end{array}$} & \multirow{2}{*}{ t-stat } & \multirow{2}{*}{ P-value } & \multirow{2}{*}{ VIF } & \multicolumn{2}{|c|}{$95 \%$ confidence interval } \\
\hline & & & & & & $\min$ & $\max$ \\
\hline const & 1304.5 & 88.185 & 14.793 & 0.00001 & & 1130.83 & 1478.2 \\
\hline Av_wagedif & -1.016 & 0.2139 & $-4 ., 749$ & 0.00001 & 1.225 & -1.4371 & -0.595 \\
\hline Wage_debt & 10.722 & 0.6775 & 15.826 & 0.00001 & 1.172 & 9.3873 & 12.056 \\
\hline Wage cos & -0.8035 & 0.0739 & -10.873 & 0.00001 & 1.054 & -0.9490 & -0.658 \\
\hline
\end{tabular}

Based on calculations for the pooled regression model, we can conclude that the increasing difference between the average wage in the EEU and region and minimum living wage leads to smaller numbers of migrants from a particular region. At the same time, growing wage arrears lead to higher numbers of migrants. Note that an inverse relationship between numbers of migrants and a wage gap is not consistent with theoretical assumptions. Based on the analysis completed, it is possible to conclude that wage arrears are the most influential factor for higher numbers of migrants with regional differentiation taken into account: a $1 \%$ increase in this indicator produces almost $5 \%$ increase in numbers of migrants.

To identify an impact of private transfers, employment level, bank loans and deposit rates in the EEU, we have completed a regression analysis and built the following models inside. The first model distinguishes an impact of private remittances, remittances as percentage of GDP (x1), exported goods and services as \% of GDP (x2) upon the employment rate of the employable population (y) (7):

$$
\mathrm{Y}=50,318+0,15 \mathrm{x}_{1}+0,00118 \mathrm{x}_{2} \text {. }
$$

Consequently, with a $1 \%$ increase in private remittances the employment level among the employable population grows by $0.15 \%$, if other factors remain unchanged. With a $1 \%$ increase in exported goods and services, the employment level of the employable increases by $0.001 \%$, if other factors remain unchanged. It is possible to consider the relationship revealed with the help of this model significant as the determination coefficient is within $50 \%$.

The second model distinguishes an impact of private remittances, remittances as percentage of GDP (x1), GDP per capita (x2) and registered unemployment rate (y) (8):

$$
Y=5,380-0,75 x_{1}-0,000004 x^{2}
$$

Hence, with a $1 \%$ increase in private remittances, registered unemployment decreases by $0.75 \%$ if factors remain unchanged. It is possible to consider the relationship (revealed with the help of this model) significant as the determination coefficient is $0.61 \%$. Completed calculations showed that private remittances had a positive impact on the unemployment rate and encouraged a growth of national GDP.

Based on the evaluated conformity of model specifications and significance of particular regressands, the following conclusions are possible regarding an impact of socio-economic and demographic factors on population migration rates in the EEU. First, we identified a direct relationship between a natural growth (decline) of the population, numbers of vacant jobs, and population migration indicator. Second, we identified an inverse relationship between GDP per capita, consumer price index, minimum wage, unemployment rate, and population 
migration indicator. Third, the research demonstrated that a direction of migrant flows depends on such factors, as GDP per capita, numbers of vacant jobs, and minimum wages.

\section{Conclusions}

Modern global development trends have a significant impact on a development and functioning of labour markets. Based on migration statistics, it is possible to refer to strengthening migration processes in EEU countries. Modelling results made it possible to identify that a decline in the difference between minimum wages has the greatest influence on activation of migratory flows. In the EEA countries, the following reasons are main for leaving for work abroad: unemployment in rural areas, lower wages compared to neighbouring states. Irregular income is a significant argument too for labour migration in the EEU.

A study of an impact of other factors for labour migration made it possible to establish that an increasing difference between average wages in a region and the EEU and a minimum living wage leads to smaller numbers of migrants from a particular region. At the same time, a growth in wage arrears leads to higher numbers of migrants.

The structural analysis says of a higher number of labour migrants among employable men, which in turn results in a worse situation in national labour markets of donor countries. There is a decline in a number of the employed by occupational group. At the same time, host countries are most interested in highly skilled workers (especially in new and promising sectors) that have experience in the field. This in turn will allow achieving substantial savings related to costs of training for professionals. Enhanced labour flows among the population of young and middle ages naturally lead to nation aging making the demographic situation worse.

A search for effective migration policy procedures is undoubtedly becoming an important task for government bodies of the EEU. Based on research findings, it is possible to improve management decisions in such fields, as quota setting for labour migrant flows, introduction of minimum wages, income taxation for migrants, etc. All these measures will help to achieve a control over labour migration and harmonization of processes. At the same time, higher flexibility in the labour market is getting especially important in the context of intercountry competition and EEA countries' joining the global division of labour. In this regard, we consider migration as a global economic phenomenon that needs its further research and evaluation of its impact on socio-economic aspects of development.

\section{References}

Baccaïni, B. (2007). Interregional Migration Flows in France over the Last Fifty Years. Population, 62, 139-155. https://doi.org/10.3917/pope.701.0139

Bijak, J., Kupiszewska, D., Kupiszewski, M., \& Saczuk, K. (2013). Population Ageing, Population Decline and Replacement Migration in Europe. In: Kupiszewski, M. (eds.), International Migration and the Future of Populations and Labour in Europe. The Springer Series on Demographic Methods and Population Analysis, 32. Dordrecht: Springer. https://doi.org/10.1007/978-90-481-8948-9 14

Brücker, H. (2002). The Employment Impact of Immigration: a Survey of European Studies.

Brucker, H. (2002). The Impact of International Migration on Welfare and Welfare State in an Enlarged Europe. Paper presented at the Oesterriche Nationalbank EastWest Conference, 35 November. 
Chernenko, E. F. (2015). Specifics of Migration Processes in the Eurasian Economic Union. Bulletin of the Moscow Institute of Humanities and Economics, 1, 50-56.

Commission on Population and Development, 46th Session. (2013). Migration: A World on the Move. Linking Population, Poverty and Development. Theme: New Trends in Migration, 22-26 April, http://www.unfpa.org/pds/migration.html

Danzer, A. M., \& Dietz, B. (2016). Temporary Labour Migration from Eastern Europe: the Role of Human Capital Investment and Migration Agencies. In: Nadler, R., Kovács, Z., Glorius, B., Lang, T. (eds.), Return Migration and Regional Development in Europe. New Geographies of Europe. London: Palgrave Macmillan. https://doi.org/10.1057/978-1-137-57509-8_6

Delogu, M., Docquier, F., \& Machado, J. (2018). Globalizing Labour and the World Economy. Journal of Economic Growth, 1-36. https://doi.org/10.1007/s10887-017-9153-Z

Department of Economic and Social Affairs. (2004). World Economic and Social Survey 2004. International Migration. NY: UN, 138.

Doeringer, P., \& Piore, M. (1971). Internal Labour Markets and Manpower Analysis. Lexington (Mass.), 13-28.

Dosaliev, B. A. (2016). Migration of Labour Resources and the EEU. Bulletin of M. Ryskulbekov Kyrgyz University of Economics, 1(35), 127-130.

Efimov, A. G., \& Katsan, V. N. (2010). Influence of Population Migration on a Regional Labour Market and Specifics of State Control over Migration Flows in Today's Russia. In: Shatokhin, M. V. (ed.), Problems and Prospects of Development in Socio-economic Systems: Coll. Papers. Kursk: KGT, 2, 19-27.

Glick, S. N., Bash, L., \& Blanc-Szanton, C. (eds.). (1992). Towards a Transnational Perspective on Migration. Race, Class, Ethnicity, and Nationalism Reconsidered. Annals of the New York Academy of Sciences, 645.

Glushchenko, G. I. (2008). Migration and Development: World Trends. Voprosy Statistiki, 2, 65-79.

Gotovtseva, L. G., Ryazantsev, A. P., \& Khrustalev, E. Yu. (2012). Financial and Economic Features and Trends in Interstate Labour Migration. Problems of Forecasting, 4, 80-85.

Haisken-DeNew, J. P., \& Zimmerman, K. F. (1995). Wage and Mobility Effects of Trade and Migration. CEPR Discussion Paper, 1318. London.

Ivanova, T. D. (2008). Labour Migration of the Russians: Economic and Social Effects (According to Results of Sociological Research). Problems of Forecasting, 4, 82-97.

Kapur, D. (2004). Remittances: the New Development Mantra. NY, Genva: UNCTAD (G-24 DPS No. 29).

Khrustalev, E. Yu., \& Slavianov, A. S. (2014). Labour Migration and the Problem of Innovative Development. Problems of Forecasting, 1, 79-86.

König, J., \& Koskela, E. (2011). Does International Outsourcing Really Lower Workers' Income? Journal of Labour Research, 32(1), 2138. https://doi.org/10.1007/s12122-010-9100-7

Kritz, M. M., Lim, L. L., \& Zlotnik, H. (eds.). (1992). International Migration Systems: A Global Approach. Oxford: Clarendon Press.

Kuzmin, E. A., \& Barbakov, O. \& M. (2015, February). Institutional Efficiency and Processes of Institutional Change (as Seen by the Russian Academic Tradition). Asian Social Science, 11(6), 163-170. https://doi.org/10.5539/ass.v11n6p163

Lindert, P. (1992). Economics of Global Economic Cooperation. Moscow

Massey, D. (2007). On the Way to a Comprehensive Model of International Migration. Migration and Development. Reports and Papers by Leading Sections and Speakers of the "Migration and Development" Intern. Conf., Moscow, September 13-15, 2007. Moscow: BielPrint, 146-172.

Massey, D. S., Arango, J., Hugo, G., Kouaouci, A., Pellegrino, A., \& Taylor, J.E. (1998). Worlds in Mind. Oxford: Clarendon Press. 
May, J. F. (2012). Population Policies in Developing Countries. In: World Population Policies. Dordrecht: Springer. https://doi.org/10.1007/978-94-007-2837-0

Micco, A., Pages, C. (2006). The Economic Effects of Employment Protection: Evidence from International Industry Level Data. Central Bank of Chile. World Bank, 6.

Namatov, Z. Zh. (2016). Trends of Labour Migration in the Kyrgyz Republic at the Present Stage. Bulletin of the Kyrgyz-Russian Slavic University, 16(2), 67-70.

Nazarov, A. D. (2012). International Labour Migration as a Factor of Diversification of Human Capital and Ensuring of Russian Demographic Security: Communication Aspect. Human Capital, 9(45), 82-86.

O'Connor, A. (2010), Investment in Human Capital, Migration and Economic Growth. In: O'Connor, A. (eds.), Managing Economies, Trade and International Business. London: Palgrave Macmillan. https://doi.org/10.1057/9780230274013

Overcoming Barriers: Human Mobility and Development. The UN Human Development Report. (2009). ISBN 978-5-7777-0457-3.

Pekarskiene, I., Laskiene, D., Saboniene, A., \& Susniene, R. (2017). The Impact of Economic Globalization on the Labour Market of an Open Small Economy. In: Bilgin, M., Danis, H., Demir, E., \& Can, U. (eds.), Financial Environment and Business Development. Eurasian Studies in Business and Economics, 4. Cham: Springer. https://doi.org/10.1007/978-3-319-39919-5_16

Portes, A., \& Rumbaut, R. G. (1990). Immigrant America: a Portrait. Los Angeles: University of California Press.

Potrafke, N. (2010). Labour Market Deregulation and Globalization: Empirical Evidence from OECD Countries. Review of World Economics, 146(3), 545-571. https://doi.org/10.1007/s10290-010-0056-8

Rayp, G. (2013). Growing Inequalities, Globalization and Trade Unions. In: Hellier, J., \& Chusseau, N. (eds.), Growing Income Inequalities. London: Palgrave Macmillan. https://doi.org/10.1057/9781137283306_7

Rees, P., van der Gaag, N., de Beer, J., \& Heins, F. (2012). European Regional Populations: Current Trends, Future Pathways, and Policy Options. European Journal of Population, 28(4), 385-416. https://doi.org/10.1007/s10680-012-9268-Z

Rodrik, D. (2002). Feasible Globalizations, Kennedy School of Government, Working Paper Series RWPO 2029, July.

Rosenau, J. N. (1993). Les processus de la Mondialisation: Retombees Significatives, Echanges Impalpables and Symbolique Subtile. Etudes Internationales, XXIV(3), 499. https://doi.org/10.7202/703206ar

Russia’s Central Bank, http://www.cbr.ru

Samrailova, E. K., \& Veshkurova, A. B. (2010). Current State and Migration Development Trends (Evidence from the Russian Federation and Kazakhstan). Labour and Social Relationship, 12, 1321.

Sassen, S. (1988). The Mobility of Labour and Capital. Cambridge University Press. https://doi.org/10.1017/CBO9780511598296

Savin, V. E., Savina, S. E. (2016). Migration is a Leading Factor in a Creation of the Unified Labour Market in the EEU. Economics, 1(26), 78-83.

Singer, H. W. (2000). Some Reflections on Trade Expansion as a Measure of Globalization. In: Metzger, M., \& Reichenstein, B. (eds.), Challenges for International Organizations in the 21 st Century. London: Palgrave Macmillan. https://doi.org/10.1007/978-1-349-62715$\underline{82}$

Suliagina, Yu. O. (2016). Methodological Approaches to the Analysis of Global Processes in Labour Migration. Proceedings of Afanasiev Readings, 2(15), 185-189.

Trofimova, T. I. (2010). Russia and International Migration Processes. In: Federal Education Agency, Baikal State University of Economics and Law, Evolution of Global Migration Processes. Irkutsk: Publishing House of Belarusian State University of Economics and Law, 75-85. 
Tsvylev, R. I., Rydvanov, N. F., \& Zhiritsky, A. K. (1994). The World Labour Market: a New Reality for Russia and the CIS. Moscow: Nauka, 30.

Usmanova, T. D., Azimova, M. T. (2017). Internationalization of the Labour Market in Market Economy in the Republic of Tajikistan. Socio-economic Phenomena and Processes, 12(3), 177-182.

World Economic and Social Survey 2004. International Migration. (2004), NY: UN, 138

\section{Annex}

Table. Data panel from research across the EEU countries for 2006-2017

\begin{tabular}{|c|c|c|c|c|c|c|c|c|c|c|c|c|}
\hline \multirow{2}{*}{ Indicators } & \multicolumn{12}{|c|}{ Research timeframe } \\
\hline & 2006 & 2007 & 2008 & 2009 & 2010 & 2011 & 2012 & 2013 & 2014 & 2015 & 2016 & 2017 \\
\hline \multicolumn{13}{|c|}{ Armenia } \\
\hline $\begin{array}{l}\text { Migration inflow (+), } \\
\text { outflow (-), persons }\end{array}$ & - & - & - & - & - & $-37,300$ & $-28,500$ & $-9,400$ & $-24,400$ & $-21,800$ & $-25,900$ & $-24,792$ \\
\hline $\begin{array}{l}\text { Number of gainfully } \\
\text { employed population, } \\
\text { thousands of people }\end{array}$ & - & - & 1,184 & 1,415 & 1,419 & 1,463 & 1,441 & 1,418 & 1,388 & 1,376 & 1,316 & 1,226 \\
\hline $\begin{array}{l}\text { Average monthly } \\
\text { nominal wage, } \$\end{array}$ & 149.7 & 217.0 & 285.7 & 264.3 & 274.7 & 290.2 & 350.3 & 357.7 & 381.3 & 359.1 & 363.1 & 404.1 \\
\hline Minimum wage, $\$$ & 41.2 & 65.8 & 81.2 & 78.8 & 83.2 & 84.8 & 80.1 & 111.0 & 107.9 & 113.9 & 113.9 & 113.8 \\
\hline \multicolumn{13}{|c|}{ Belarus } \\
\hline $\begin{array}{l}\text { Migration inflow (+), } \\
\text { outflow (-), persons }\end{array}$ & 1,949 & 5,626 & 4,676 & 8145 & 12,249 & 10,303 & 9,900 & 9,328 & 11,643 & 15,722 & 18,494 & 7,940 \\
\hline $\begin{array}{l}\text { Number of gainfully } \\
\text { employed population, } \\
\text { thousands of people }\end{array}$ & - & - & 4,567 & 4654 & 4,686 & 4,742 & 4,723 & 4,641 & 4,602 & 4,573 & 4,537 & 5,164 \\
\hline $\begin{array}{l}\text { Average monthly } \\
\text { nominal wage, } \$\end{array}$ & 271.2 & 323.0 & 403.9 & 350.2 & 406.6 & 338.9 & 439.2 & 564.2 & 589.9 & 413.1 & 361.4 & 421.7 \\
\hline Minimum wage, \$ & 77.1 & 87.4 & 100.1 & 85.5 & 132.2 & 109.8 & 136.5 & 162.0 & 167.4 & 121.0 & 121.9 & 131.8 \\
\hline \multicolumn{13}{|c|}{ Kazakhstan } \\
\hline $\begin{array}{l}\text { Migration inflow (+), } \\
\text { outflow (-), persons }\end{array}$ & 22,668 & 33,041 & 10,962 & 1,300 & 7,526 & 15,516 & 5,096 & $-1,426$ & -328 & $-12,162$ & $-13,466$ & $-21,145$ \\
\hline $\begin{array}{l}\text { Number of gainfully } \\
\text { employed population, } \\
\text { thousands of people }\end{array}$ & & & 8,228 & 8,415 & 8,458 & 8,611 & 8,775 & 8,982 & 9,041 & 8,962 & 9,075 & 8,999 \\
\hline $\begin{array}{l}\text { Average monthly } \\
\text { nominal wage, } \$\end{array}$ & 323.5 & 428.2 & 505.4 & 456.5 & 526.7 & 614.0 & 679.1 & 717.4 & 675.4 & 568.4 & 417.6 & 459.1 \\
\hline Minimum wage, \$ & 71.9 & 80.7 & 99.7 & 92.3 & 101.4 & 108.2 & 115.9 & 121.1 & 109.8 & 66.2 & 68.5 & 73.3 \\
\hline \multicolumn{13}{|c|}{ Kyrgyzstan } \\
\hline $\begin{array}{l}\text { Migration inflow (+), } \\
\text { outflow (-), persons }\end{array}$ & - & - & - & - & - & $-50,628$ & $-39,403$ & $-7,487$ & $-7,203$ & $-7,757$ & $-4,229$ & $-3,965$ \\
\hline $\begin{array}{l}\text { Number of gainfully } \\
\text { employed population, } \\
\text { thousands of people }\end{array}$ & - & - & 2,344 & 2,380 & 2,420 & 2,456 & 2,490 & 2,497 & 2,469 & 2,504 & 2,544 & 2,547 \\
\hline $\begin{array}{l}\text { Average monthly } \\
\text { nominal wage, } \$\end{array}$ & 81.4 & 106.4 & 147.1 & 143.6 & 156.4 & 201.6 & 228.2 & 234.1 & 229.0 & 209.2 & 212.4 & 223.5 \\
\hline Minimum wage, \$ & 2.6 & 9.7 & 8.6 & 7.7 & 10.6 & 14.8 & 16.0 & 17.1 & 15.5 & 12.8 & 15.3 & 17.2 \\
\hline \multicolumn{13}{|c|}{ Russia } \\
\hline $\begin{array}{l}\text { Migration inflow (+), } \\
\text { outflow (-), persons }\end{array}$ & 107,432 & 132,319 & 239,943 & 242,106 & 247,449 & 158,078 & 319,761 & 294,930 & 295,858 & 270,036 & 245,384 & 261,948 \\
\hline $\begin{array}{l}\text { Number of gainfully } \\
\text { employed population, } \\
\text { thousands of people }\end{array}$ & - & - & 75,289 & 75,700 & 75,694 & 75,478 & 75,779 & 75,676 & 75,529 & 75,428 & 76,588 & 76,636 \\
\hline $\begin{array}{l}\text { Average monthly } \\
\text { nominal wage, } \$\end{array}$ & 391.2 & 531.6 & 696.9 & 588.3 & 690.1 & 796.2 & 857.1 & 936.3 & 855.8 & 561.0 & 548.8 & 671.0 \\
\hline Minimum wage, \$ & 41.8 & 93.6 & 81.8 & 144.6 & 140.4 & 146.6 & 150.0 & 158.3 & 100.2 & 85.6 & 120.6 & 133.1 \\
\hline
\end{tabular}


Georgi N. TODOROV, Assistant professor, Center of Social and Economic Development of the Varna Scientific Institute of the Eastern European Commonwealth - VSIEEC. Research interests: information and economic security, project management, energy efficiency, agricultural sector, business planning, employment and labor relations.

ORCID ID: orcid.org/0000-0001-6603-4084

Anna V. KALININA, Cand. Sci. (Historical), Associate professor, Department of marketing and municipal management, Tyumen Industrial University. Research interests: non-commercial advertising, mass communications, employment, territory branding, problems of society, economic history.

ORCID ID: orcid.org/0000-0001-6086-8387

Anna I. RYBAKOVA, Cand. Sci. (Psychological), Associate Professor, Dean of the faculty of additional vocational education of the Russian State Social University. Research interests: education, social psychology, complementary education, poverty, social work, labor relations, social and economic development.

ORCID ID: orcid.org/0000-0002-7816-8407

Register for an ORCID ID:

https://orcid.org/register

Copyright (C) 2018 by author(s) and VsI Entrepreneurship and Sustainability Center

This work is licensed under the Creative Commons Attribution International License (CC BY).

http://creativecommons.org/licenses/by/4.0/

CC) (i) Open Access 